\title{
AMP-activated protein kinase regulates glucagon secretion from mouse pancreatic alpha cells
}

\author{
I. Leclerc • G. Sun • C. Morris • E. Fernandez-Millan • \\ M. Nyirenda • G. A. Rutter
}

Received: 11 May 2010 /Accepted: 1 September 2010 /Published online: 13 October 2010

(C) Springer-Verlag 2010

\begin{abstract}
Aim/hypothesis AMP-activated protein kinase (AMPK), encoded by Prkaa genes, is emerging as a key regulator of overall energy homeostasis and the control of insulin secretion and action. We sought here to investigate the role of AMPK in controlling glucagon secretion from pancreatic islet alpha cells.

Methods AMPK activity was modulated in vitro in clonal alphaTC1-9 cells and isolated mouse pancreatic islets using pharmacological agents and adenoviruses encoding constitutively active or dominant negative forms of AMPK. Glucagon secretion was measured during static incubation by radioimmunoassay. AMPK activity was assessed by both direct phosphotransfer assay and by western (immuno-)
\end{abstract}

I. Leclerc and G. Sun contributed equally to this study.

Electronic supplementary material The online version of this article (doi:10.1007/s00125-010-1929-z) contains supplementary material, which is available to authorised users.

I. Leclerc $\cdot$ G. Sun $\cdot$ E. Fernandez-Millan $\cdot$ M. Nyirenda $\cdot$

G. A. Rutter $(\bowtie)$

Section of Cell Biology, Division of Diabetes,

Endocrinology and Metabolism, Faculty of Medicine,

Imperial College,

London, UK

e-mail: g.rutter@imperial.ac.uk

C. Morris

Department of Electrical and Electronic Engineering,

Faculty of Engineering, Imperial College,

London, UK

Present Address:

E. Fernandez-Millan

Universidad Complutense, School of Pharmacy,

Madrid, Spain blotting of the phosphorylated AMPK $\alpha$ subunits and the downstream target acetyl-CoA carboxylase 1. Intracellular free $\left[\mathrm{Ca}^{2+}\right]$ was measured using Fura-Red.

Results Increasing glucose concentrations strongly inhibited AMPK activity in clonal pancreatic alpha cells. Forced increases in AMPK activity in alphaTC1-9 cells, achieved through the use of pharmacological agents including metformin, phenformin and A-769662, or via adenoviral transduction, resulted in stimulation of glucagon secretion at both low and high glucose concentrations, whereas AMPK inactivation inhibited both $\left[\mathrm{Ca}^{2+}\right]_{\mathrm{i}}$ increases and glucagon secretion at low glucose. Transduction of isolated mouse islets with an adenovirus encoding AMPK-CA under the control of the preproglucagon promoter increased glucagon secretion selectively at elevated glucose concentrations.

Conclusions/interpretation AMPK is strongly regulated by glucose in pancreatic alpha cells, and increases in AMPK activity are sufficient and necessary for the stimulation of glucagon release in vitro. Modulation of AMPK activity in alpha cells may therefore provide a novel approach to controlling blood glucose concentrations.

Keywords AMP-activated protein kinase .

Glucagon secretion · Pancreatic alpha cells .

Pancreatic islets of Langerhans

Abbreviations
$\begin{array}{ll}\text { ACC } & \text { Acetyl-CoA carboxylase } \\ \text { AICAR } & 5 \text {-Aminoimidazole-4-carboxamide } \\ & 1-\beta \text {-D-ribofuranoside } \\ \text { AMPK } & \text { AMP-activated protein kinase } \\ {\left[\mathrm{Ca}^{2+}\right]_{\mathrm{i}}} & \text { Free intracellular calcium concentration } \\ \text { GFP } & \text { Green fluorescent protein }\end{array}$




$\begin{array}{ll}\text { KBH } & \text { Krebs' Ringer bicarbonate HEPES buffer } \\ \text { MOI } & \text { Multiplicity of infection } \\ \text { PPG } & \text { Preproglucagon } \\ \text { PVDF } & \text { Polyvinylidene fluoride }\end{array}$

\section{Introduction}

In mammals, glucagon is the main anti-hypoglycaemic hormone. It is secreted by the pancreatic alpha cells of the islets of Langerhans in response to hypoglycaemia, and quickly restores normoglycaemia by stimulating hepatic glucose output. Male mice lacking a functional glucagon receptor $\left(\mathrm{Gcgr}^{--}\right)$experienced frank hypoglycaemia during insulin tolerance tests and severe hypoglycaemia during a $24 \mathrm{~h}$ fast together with reduced glucose levels throughout the day [1].

Hypoglycaemia induces glucagon release both as a result of changes in parasympathetic and sympathetic tone [2], increases in circulating adrenaline (epinephrine) levels and through direct effects of glucose on pancreatic alpha cells [3]. The exact natures of the latter are still debated, and how glucose exerts its action on individual alpha cells is still unclear. We have presented a substantial amount of data supporting the view that, at least in the mouse, a direct effect of glucose and an indirect effect of $\gamma$-amino butyric acid, released from beta cells, are the principal means through which glucagon secretion is regulated [4]; by contrast, roles for released $\mathrm{Zn}^{2+}$ ions and for insulin appear to be less important acutely, although the latter is undoubtedly important in the control of preproglucagon gene expression [5].

AMP-activated protein kinase (AMPK) is a highly conserved multisubstrate serine/threonine protein kinase, which acts as a nutrient sensor [6] that has evolved to execute responses to starvation [7]. Mammalian AMPK is composed of three subunits: one catalytic subunit, $\alpha$, and two regulatory subunits, $\beta$ and $\gamma$. AMPK complexes are activated by phosphorylation of the $\alpha$ subunits on threonine-172 both by $\mathrm{Ca}^{2+} /$ calcium mitogen-activated protein kinase kinase $\beta$ and by AMP/liver kinase B1 (STK11)-dependent signals following metabolic stresses [7-10]. Once activated, AMPK stimulates catabolic pathways that generate ATP, while inhibiting cell growth and biosynthesis and other processes that consume ATP.

In yeast, AMPK allows growth in the absence of glucose and switches cellular metabolism to use alternative carbon sources [11]; in plants, AMPK allows survival in alternate cycles of light and darkness, as opposed to light only [12]; finally, in Caenorhabditis elegans, the enzyme preserves lipid stores to allow long-term survival during periods of fasting [13]. In the mammalian brain,
AMPK is activated by neuroglucopenia and is necessary for triggering the counter-regulatory response to correct hypoglycaemia. In rats, previous intracerebroventricular administration of compound C (an AMPK inhibitor) [14] attenuated hypoglycaemia-induced increases in plasma concentrations of corticosterone, glucagon and catecholamines, resulting in severe and prolonged hypoglycaemia [15]. Counter-regulatory hormone responses were impaired by recurrent neuroglucopenia, induced daily by intracerebroventricular injections of 2-deoxy-D-glucose and were partially restored by intracerebroventricular injection of 5-aminoimidazole-4-carboxamide 1- $\beta$-D-ribofuranoside (AICAR, an AMPK activator) [16, 17], and during hypoglycaemic clamp studies, stimulation of AMPK within the ventromedian hypothalamus by AICAR was found to amplify the hormonal counter-regulatory response and increase endogenous glucose production [18].

Consistent with its pre-eminent role in preserving glucose levels in periods of food deprivation, we, and others, have also shown that AMPK activation by low glucose inhibits insulin vesicle dynamics and insulin secretion in beta cells of pancreatic islet of Langerhans [19-22], while AMPK activation in vivo diminishes transplanted islet survival in diabetic mice [23] and insulin secretion in transgenic mice expressing an activated form of the enzyme selectively in the beta cell [24]. We therefore hypothesised that AMPK activity may also be regulated by glucose in alpha cells within the pancreatic islet, and in this way might control glucagon secretion.

We show here that low glucose strongly activates AMPK in pancreatic alpha cells and that this activation is both necessary and sufficient for the stimulation of glucagon release by glucose withdrawal, in vitro.

\section{Methods}

Reagents and antibodies AICAR, metformin and phenformin were purchased from Sigma (Poole, UK). Compound C was obtained from Calbiochem (VWR, Lutterworth, UK) and compound A-769662 was a kind gift from Prof. G. Hardie (University of Dundee, Dundee, UK). Fura-Red AM was obtained from Invitrogen (Paisley, UK). Collagenase from Clostridium histolyticum was obtained from Serva Electrophoresis (Heidelberg, Germany); rabbit antiphospho-ACC (ser 79) and anti-AMPK ( $\alpha$-pan) were obtained from Millipore (Watford, UK) and anti-phosphoAMPK (Thr-172) was supplied by Cell Signalling (NEB, Hitchin, UK). Monoclonal anti-tubulin antibody was from Sigma; monoclonal rabbit anti-glucagon antibody was from Dako (Ely, UK) and mouse anti-c-myc antibody was from Roche (Burgess Hill, UK). All other reagents were from Sigma or Invitrogen. 
Adenoviruses Adenoviruses encoding green fluorescent protein and dominant negative AMPK under the cytomegalovirus promoter (CMV-GFP or null and CMV-AMPK-DN) are described elsewhere [20]. An adenovirus encoding constitutionally active AMPK under the preproglucagon promoter (PPG-AMPK-CA) was generated according to previous studies $[25,26]$ by first sub-cloning the $1.6 \mathrm{~kb}$ SacI fragment of the rat PPG promoter (a generous gift from J. Philippe, Université de Genève, Switzerland) upstream of the c-myctagged, truncated, constitutively active AMPK $\alpha 1^{312}$ (residues 1-312; AMPK CA) with a Thr-172-to-Asp mutation cDNA [27] followed by the poly(A) from pCDNA3 in pBluescript II $\mathrm{KS}+$, and then by amplifying this whole cassette by Phusion Hot Start High-Fidelity DNA Polymerase (Finnzymes, NEB, Hitchin, UK) using M13 universal primers. The resulting PCR product was then phosphorylated using T4 polynucleotide kinase and sub-cloned at the dephosphorylated EcoRV site in pAd-Track enhancer. The pAd-Track enhancer was generated by inserting the simian virus 40 enhancer from pGL2 enhancer (Promega, Southampton, UK), generated by PCR, using the following primers: (forward) 5'-CGC GTC TAG AAG GGG TTA ATA AGG AAT AT, (reverse) 5'-CGC GTC TAG AAG CTG ACT GGG TTG AAG G, (XbaI sites underlined) at the $X b a \mathrm{I}$ site of pAd-TrackCMV [25]. Both AMPK-DN and AMPK-CA adenoviruses also encode GFP under a distinct CMV promoter.

AlphaTC1-9 cell culture AlphaTC1-9 cells (a mouse alpha cell line, passage 35-45; American Type Culture Collection, Manassas, VA, USA) were grown in Dulbecco's modified Eagle's medium containing $18 \mathrm{mmol} / 1 \mathrm{NaHCO}_{3}$, $16 \mathrm{mmol} / 1$ glucose, $0.1 \mathrm{mmol} / 1 \mathrm{non}$-essential amino acids, $10 \%$ heat-inactivated $\mathrm{FCS}, 100 \mathrm{IU} / \mathrm{ml}$ penicillin and $100 \mu \mathrm{g} / \mathrm{ml}$ streptomycin in a humidified atmosphere containing $5 \% \mathrm{CO}_{2}$, unless specified otherwise, as described previously [5].

Islet isolation Islets of Langerhans from 12-week-old female CD1 mice (Harlan, Blackthorn, Bicester, UK) were isolated and cultured as described elsewhere [28], in accordance with the UK Home Office Animals Scientific Procedures Act, 1986. Islets were infected with adenoviruses at a multiplicity of infection (MOI) of 100 plaqueforming units/cell and cultured for a further $48 \mathrm{~h}$ before measurement of glucagon and insulin secretion.

Total cellular ATP content After experimental manipulations, cells were extracted into ice-cold perchloric acid ( $20 \%$ vol./vol., $200 \mu \mathrm{l}$ ), thawed and adjusted to $\mathrm{pH} 7.4$ with a known volume of neutralisation mixture $(0.5 \mathrm{~mol} / \mathrm{l}$ triethanolamine, $2 \mathrm{~mol} / \mathrm{l} \mathrm{KOH}, 100 \mathrm{mmol} / \mathrm{l}$ EDTA). Precipitated potassium perchlorate was removed by centrifugation $\left(16,000 \mathrm{~g}\right.$ for $2 \mathrm{~min}$ at $\left.4^{\circ} \mathrm{C}\right)$ and the supernatant was stored on ice before assay. Neutralised sample $(10 \mu \mathrm{l})$ was added to $1 \mathrm{ml}$ assay buffer $\left(130 \mathrm{mmol} / 1 \mathrm{NaHAsO}_{4}, 17 \mathrm{mmol} / 1 \mathrm{MgSO}_{4}\right.$, $4 \mu \mathrm{mol} / 1 \mathrm{NaH}_{2} \mathrm{PO}_{4}, \mathrm{pH} 7.4$ ) and the reaction was initiated with $10 \mu \mathrm{g}$ firefly lantern extract $(10 \mathrm{mg} / \mathrm{ml} \mathrm{stock}$; Sigma). Light emission was recorded for $30 \mathrm{~s}$ using a photoncounting luminometer (LB-9501; EG\&G Berthold, Bad Wildbad, Germany). An ATP standard curve $(0-50 \mathrm{pmol} /$ $\mu \mathrm{l})$ was prepared in parallel with the cell extracts. Protein content of cells incubated in parallel but extracted as for western blot was determined using a bicinchoninic protein assay kit (Pierce, Rockford, IL, USA).

Total AMPK activity AMPK activity measurements were performed as described previously [21]. Briefly, to determine total AMPK activity in alphaTC1-9 cells, $20 \mu \mathrm{g}$ total protein extract from alphaTC1-9 cells lysed in $100 \mu \mathrm{l}$ ice-cold lysis buffer (mmol/l: 50 Tris- $\mathrm{HCl}\left[\mathrm{pH} 7.4,4^{\circ} \mathrm{C}\right], 250$ sucrose, 50 $\mathrm{NaF}, 1$ sodium pyrophosphate, 1 EDTA, 1 EGTA, 1 dithiothreitol, 0.1 benzamidine, and 0.1 phenylmethylsulphonyl fluoride, $5 \mu \mathrm{g} / \mathrm{ml}$ soybean trypsin inhibitor, and $1 \%$ [vol./vol.] Triton X-100) were used with synthetic SAMS peptide (HMRSAMSGLHLVKRR) as substrate. Results were expressed as ratio of cpm from cells expressing null-GFP at $0.1 \mathrm{mmol} / 1$ glucose.

Western (immuno-) blotting Cells were scraped into icecold lysis buffer (mmol/l: Tris- $\mathrm{HCl} \mathrm{pH} 7.450 \mathrm{mmol} / \mathrm{l}$, sucrose $250 \mathrm{mmol} / \mathrm{l}, \mathrm{NaF} 50 \mathrm{mmol} / \mathrm{l}$, pyrophosphate sodium $1 \mathrm{mmol} / \mathrm{l}$, EDTA $1 \mathrm{mmol} / \mathrm{l}$, dithiothreitol $1 \mathrm{mmol} / \mathrm{l}$, benzamidine $0.1 \mathrm{mmol} / \mathrm{l}$, phenylmethylsulphonyl fluoride $0.1 \mathrm{mmol} / \mathrm{l}$, soybean trypsin inhibitor $5 \mu \mathrm{g} / \mathrm{ml}$, Triton X-100 $1 \%)$, vortex-mixed and centrifuged $\left(16,000 \mathrm{~g} ; 5 \mathrm{~min} ; 4^{\circ} \mathrm{C}\right)$. Protein content was assayed using a bicinchoninic protein assay kit (Pierce), against BSA Type V (Sigma) standards. Total protein extracts $(50-80 \mu \mathrm{g})$ were subjected to SDSPAGE on $7-10 \%$ polyacrylamide gels and transferred to polyvinylidene fluoride (PVDF) membranes. After transferring, the filters were blocked with $5 \%$ non-fat dry milk in TBS-Tween $0.1 \%$ for $1 \mathrm{~h}$ at room temperature, followed by incubation with primary antibodies overnight: phosphoAMPK- $\alpha$ (Thr172) 1:1000; anti-AMPK- $\alpha$ pan-rabbit 1:4,000 (NEB, Hitchin, UK); anti-phospho-Acetyl-CoA Carboxylase $\left(\mathrm{Ser}^{79}\right.$ ) 1:1,000 (ACC1; Millipore). The PVDF filters were then washed four times for $10 \mathrm{~min}$ each time with TBS-Tween $0.1 \%$, followed by $1 \mathrm{~h}$ of incubation with anti-rabbit secondary antibody conjugated to horseradish (1:5,000, Amersham). The PVDF filters were then washed as indicated above and subsequently exposed to an enhanced chemiluminescence reagent (Amersham Life Science, Little Chalfont, UK).

Glucagon secretion AlphaTC1-9 cells seeded in 12-well plates or intact isolated mouse islets (13 per condition, size- 
matched) were pre-incubated in modified Krebs' Ringer bicarbonate HEPES $(\mathrm{KBH})$ solution $(\mathrm{mmol} / \mathrm{l}: 130 \mathrm{NaCl}$, $3.6 \mathrm{KCl}, 1.5 \mathrm{CaCl}_{2}, 0.5 \mathrm{MgSO}_{4}, 0.5 \mathrm{KH}_{2} \mathrm{PO}_{4}, 2 \mathrm{NaHCO}_{3}$, 10 HEPES, $1.5 \mathrm{CaCl}_{2}$ and $0.1 \%$ [wt/vol.]) BSA, [pH 7.4 with $\mathrm{NaOH}$ ], equilibrated for 10 min with $\mathrm{O}_{2} / \mathrm{CO}_{2}$ [95:5, vol./vol.) at $37^{\circ} \mathrm{C}$ ) containing $10 \mathrm{mmol} / 1$ glucose for $30 \mathrm{~min}$ before being incubated in $\mathrm{KBH}$ solution containing the indicated glucose concentrations in the presence or absence of other additions, as given, for $1 \mathrm{~h}$ at $37^{\circ} \mathrm{C}$ with gentle agitation. Supernatant containing secreted glucagon was collected and total glucagon content was extracted from cells or islets into $1 \mathrm{ml}$ of acid-ethanol-Triton solution (1.5\% [vol./vol.] HCl, 75\% [vol./vol.] ethanol, $0.1 \%$ [vol./ vol.] Triton X-100) for glucagon measurement using an immunoradioassay with $\mathrm{I}^{125}$-labelled glucagon antibody (Glucagon RIA kit; Millipore). To measure glucagon secretion from cells overexpressing AMPK-CA and AMPK-DN, alphaTC1-9 cells were infected with either null-GFP, AMPK-CA or AMPK-DN adenoviruses for $48 \mathrm{~h}$ at MOI 100 units/cell before glucagon assay as above.

Measurements of cytoplasmic free $\mathrm{Ca}^{2+}$ concentration $\left(\left[\mathrm{Ca}^{2+}\right]_{c y t}\right)$ AlphaTC1-9 cells were incubated in $\mathrm{KBH}$ solution containing $10 \mathrm{mmol} / \mathrm{l}$ glucose and $200 \mathrm{nmol} / \mathrm{l}$ FuraRed AM (Invitrogen) for $30 \mathrm{~min}$, essentially as described previously [29]. Cells were stimulated using the conditions indicated in the figures and excited at $480 / 440 \mathrm{~nm}$ using an Olympus IX-81 microscope coupled to an F-view camera and captured using CELL^R software (Olympus, UK) on a $40 \times$ oil objective. Data were expressed as the ratio of the fluorescence emission at $440 / 480 \mathrm{~nm}$.

Immunocytochemistry AlphaTC1-9 cells fixed with 3.7\% (vol./vol.) formalin for 15 min were permeabilised with $0.1 \%$ (vol./vol.) Triton for $5 \mathrm{~min}$. After being washed in PBS three times, cells were incubated in blocking buffer (3\% [wt/vol.] BSA dissolved in PBS) for $1 \mathrm{~h}$. Cells were subsequently incubated with primary antibodies diluted in blocking buffer at $4^{\circ} \mathrm{C}$ overnight. After washing three times in PBS, cells were incubated with fluorophoreconjugated secondary antibodies (Invitrogen) for $1 \mathrm{~h}$. Cells were then mounted onto slides with Vectorshield (Vector Laboratory, Peterborough, UK) and visualised under fluorescent microscopy using a Zeiss Axiovert-200 confocal microscope with an Improvision/Nokigawa spinning disc and running vOLOCITY 5.0 (Improvision, Coventry, UK) software.

Statistic analysis Data are given as means \pm SEM of three to five individual experiments. Comparisons between means were performed using two-tailed Student's $t$ test for unpaired data, with Bonferroni correction for multiple tests where appropriate.

\section{Results}

AMPK activity is inhibited by glucose in alphaTC1-9 cells and correlates with changes in total ATP content As AMPK activity is regulated by changes in AMP:ATP ratio, we first sought to measure total cellular ATP content in response to changes in glucose concentration in the relatively well-differentiated murine clonal alphaTC1-9 cell line. We have previously reported that glucagon secretion from these cells is progressively inhibited as glucose concentrations are raised from $0 \mathrm{mmol} / \mathrm{l}$, reaching saturation at glucose $\geq 1 \mathrm{mmol} / 1$ [5]. Correspondingly, and as shown in Fig. 1a, incubation of these cells for $60 \mathrm{~min}$, at increasing glucose concentrations, resulted in a sharp increase in total cellular ATP content. This was close to maximum at $1.0 \mathrm{mmol} / 1$ glucose but was slightly higher when cells were incubated at $17 \mathrm{mmol} / 1$ glucose.

We next assessed AMPK and ACC1 (a downstream target of AMPK) phosphorylation in this cell type in response to high glucose or $1 \mathrm{mmol} / \mathrm{l}$ AICAR, a cell permeant analogue of AMP and well known AMPK activator [16]. Consistent with the effects of glucose on ATP levels, AMPK $\alpha$ subunit and ACC1 phosphorylation were greatly reduced in cells incubated in 1 or $17 \mathrm{mmol} / \mathrm{l}$ glucose vs $0 \mathrm{mmol} / \mathrm{l}$ glucose. Surprisingly, however, AICAR was ineffective in activating AMPK in this cell type (Fig. 1b,c).

Pharmacological and molecular activation or inactivation of AMPK stimulate and inhibit glucagon secretion, respectively Given the findings above that glucose, over the range of concentrations that regulate glucagon concentration in alphaTC1-9 cells [5], powerfully regulated AMPK, we next sought to impose changes in the activity of this enzyme and explore the impact on hormone release. Metformin and phenformin are biguanides that are thought to activate AMPK activity through inhibition of complex I of the mitochondrial respiratory chain [30], therefore increasing cellular AMP/ATP ratios. By contrast, a new compound from Abbott Laboratories (Maidenhead, UK), A-769662, is a thienopyridone drug that selectively activates AMPK allosterically, by targeting $\beta 1$-containing complexes $[8,31$, 32]. As shown in Fig. $2 a$ and Electronic supplementary material (ESM) Fig. 1a, incubation of alphaTC1-9 cells for $16 \mathrm{~h}$ (to allow sufficient time for intracellular accumulation of the drug) [33] with concentrations of metformin ranging from 10 to $500 \mu \mathrm{mol} / 1$ resulted in a dose-dependent increase in AMPK and ACC phosphorylation. Incubation with metformin also markedly increased glucagon secretion, which was no longer suppressed by elevated glucose concentrations (Fig. 2b). Compound A-7769662 (Fig. 2c) and phenformin (Fig. 2e and ESM Fig. 1c) also increased AMPK and ACC1 phosphorylation in alphaTC1-9 cells, 
a

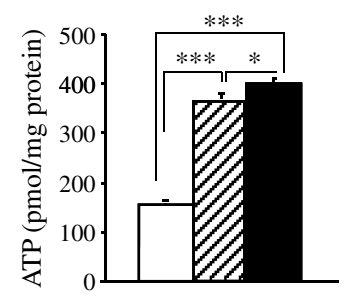

b

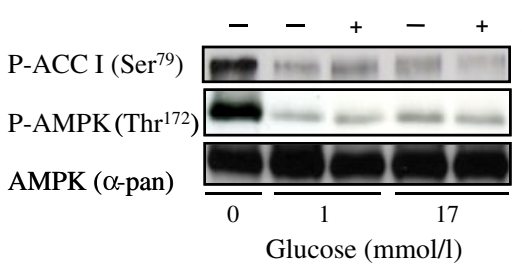

C

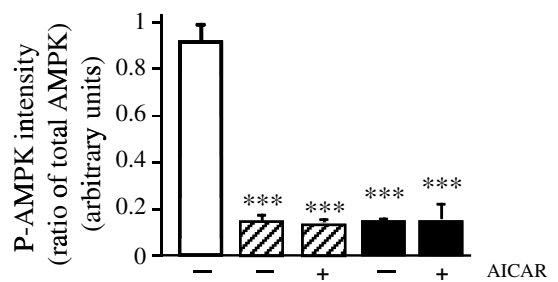

Fig. 1 Effects of glucose on total ATP cellular content and AMPK and ACC phosphorylation in alphaTC1-9 cells. a AlphaTC1-9 cells were incubated for $1 \mathrm{~h}$ in $\mathrm{KBH}$ solution containing the indicated concentrations of glucose before extraction into perchloric acid for total ATP assay. White bar, $0 \mathrm{mmol} / \mathrm{l}$ glucose; hatched bar, $1 \mathrm{mmol} / 1$ glucose; black bar, $17 \mathrm{mmol} / \mathrm{l}$ glucose. Data represent the means $\pm \mathrm{SE}$ of at least four independent experiments. $* * * p<0.001$ for the effect of 1 and $17 \mathrm{mmol} / 1$ vs $0 \mathrm{mmol} / 1$ glucose; $* p<0.05$ for the effect of $17 \mathrm{mmol} / 1$ vs $1 \mathrm{mmol} / 1$ glucose. b AlphaTC1-9 cells were incubated for $1 \mathrm{~h}$ in
$\mathrm{KBH}$ buffer containing the indicated concentrations of glucose and $1 \mathrm{mmol} / \mathrm{l}$ AICAR as shown. Cell lysis and inmunoblotting using $15 \mu \mathrm{g}$ protein per lane were performed as described in the Methods. A representative blot of at least four independent experiments is shown. c Quantification of four blots shown in $\mathbf{b}$. Data represent the means $\pm \mathrm{SE}$ of at least four independent experiments. ${ }^{* * *} p<0.001$ for the effect of 1 or $17 \mathrm{mmol} / 1$ glucose. White bar, $0 \mathrm{mmol} / 1$ glucose; hatched bars, $1 \mathrm{mmol} / 1$ glucose; black bars, $17 \mathrm{mmol} / 1$ glucose after 30 to $60 \mathrm{~min}$ incubation, and stimulated glucagon secretion at both permissive $(0.1 \mathrm{mmol} / \mathrm{l})$ and inhibitory $(17 \mathrm{mmol} / \mathrm{l})$ levels of glucose (Fig. 2d,f). By contrast, compound C (an AMPK inhibitor) [14] inhibited both AMPK and ACC1 phosphorylation and glucagon release (Fig. 2e,f).

We subsequently modulated AMPK activity molecularly by using adenoviruses encoding constitutively active or dominant negative forms of the kinase [27]. AlphaTC1-9 cells were transduced for $48 \mathrm{~h}$ at an MOI of 100 units/cell with either Null-GFP, AMPK-CA or AMPK-DN adenoviruses before incubation in 0.1 or $17 \mathrm{mmol} / \mathrm{l}$ glucose and subsequent cell lysis, for measurement of AMPK activity (Fig. 3a), or assay of glucagon secretion (Fig. 3b,c). Strikingly, forced activation of AMPK activity at $17 \mathrm{mmol} / \mathrm{l}$ glucose was sufficient to stimulate glucagon secretion, whereas forced inhibition of AMPK activity at $0 \mathrm{mmol} / \mathrm{l}$ glucose blunted glucagon secretion, confirming an essential role of AMPK in controlling glucagon secretion from alpha cells.

Inhibition of AMPK prevents cytosolic $\mathrm{Ca}^{2+}$ increases in response to low glucose in alphaTC1-9 cells We next examined changes in intracellular free calcium ion concentration $\left(\left[\mathrm{Ca}^{2+}\right]_{\mathrm{i}}\right)$ in alphaTC1-9 cells induced by glucose or by depolarisation with $\mathrm{KCl}$ following forced changes in AMPK activity achieved by adenoviral infection of AMPK$\mathrm{CA}$ and AMPK-DN. As assessed using the intracellularly trappable $\mathrm{Ca}^{2+}$ probe Fura-red, expression of AMPK-CA did not modify the $\left[\mathrm{Ca}^{2+}\right]_{\mathrm{i}}$ increases induced by low glucose or by $\mathrm{KCl}$ compared with those in null virusinfected cells (Figs 4a,b and 5a,b). By contrast, transduction of cells with AMPK-DN adenovirus essentially abolished the $\left[\mathrm{Ca}^{2+}\right]_{\mathrm{i}}$ response induced by either low glucose or $\mathrm{KCl}$
(Figs $4 \mathrm{c}$ and 5a,b). Moreover, and in contrast to the effects of AMPK-CA, AMPK-DN overexpression significantly lowered apparent basal free $\left[\mathrm{Ca}^{2+}\right]_{\mathrm{i}}$ (Fig. 5c).

Selective activation of AMPK in primary alpha cells within intact mouse islets stimulates glucagon release To extend the findings above in clonal cells to a more physiological preparation, we next modulated AMPK activity specifically in primary alpha cells within intact mouse islets and measured glucagon release in response to changes in glucose concentration. Isolated mouse islets were infected with an adenovirus in which constitutively-active AMPK was expressed under the control of the PPG promoter PPGAMPK-CA, $48 \mathrm{~h}$ before glucagon assay. To assess the efficiency of alpha cell transduction with the PPG-AMPK$\mathrm{CA}$ adenovirus, infected mouse islets were dissociated and the alpha cells were identified by immunohistochemistry using an anti-glucagon antibody. As shown in Fig. 6a, about $60 \%$ of the alpha cells (as identified with an anti-glucagon primary antibody and a Texas-red-conjugated secondary antibody) were transduced with the adenovirus (identified via GFP fluorescence; note that whereas viral infection and expression of GFP under the CMV promoter was not limited to glucagon-expressing cells, that AMPK-CA expression was expected to be restricted to alpha cells by the PPG promoter). Even with this relatively low transduction of the alpha cells, we observed a significant increase in glucagon secretion, selectively at high (inhibitory) glucose concentrations, in islets infected with PPG-AMPK-CA adenovirus compared with those infected with null-GFP virus (Fig. 6b). By contrast, no significant difference was apparent in the release of insulin from AMPK-CA vs null-GFP islets (Fig. 6c), excluding an indirect effect via altered paracrine signalling from beta to alpha cells. 


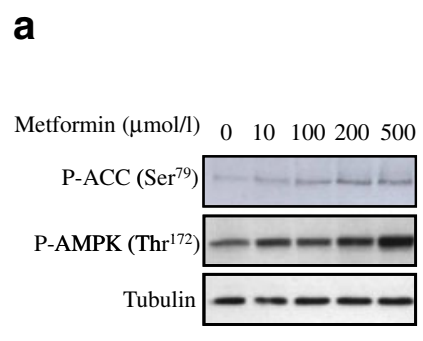

C

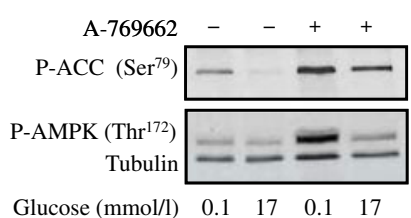

e

Glucose (mmol/l) $\quad 0 \quad 17 \quad 0 \quad 17 \quad 0 \quad 17$

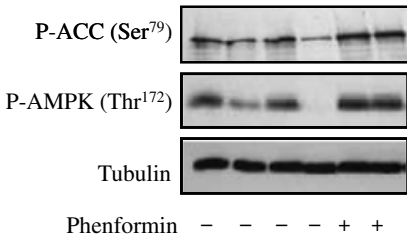

Phenformin $-\quad-\quad-\quad+\quad+$
Compound $\mathrm{C}-{ }_{-}+{ }^{-}+-$ b

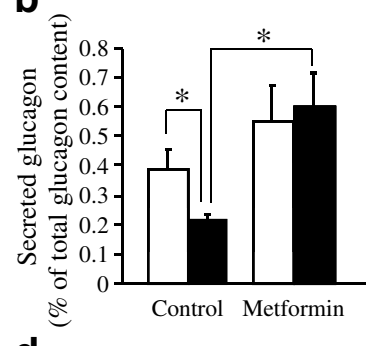

d

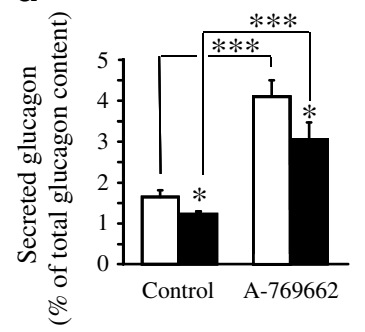

f

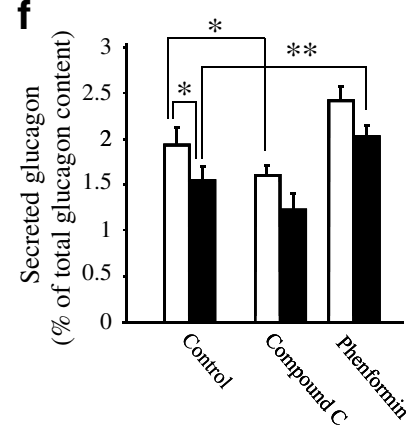

Fig. 2 Effects of pharmacological activation and inhibition of AMPK activity on AMPK and ACC phosphorylation and glucagon secretion in alphaTC1-9 cells. a Western blot (immuno-) analysis of alphaTC1-9 cells treated with metformin. AlphaTC1-9 cells incubated for $16 \mathrm{~h}$ in Dulbecco's modified Eagle's media (DMEM) containing $17 \mathrm{mmol} / 1$ glucose plus metformin at the concentrations indicated were subjected to western (immuno-)blotting analysis using $50 \mu \mathrm{g}$ protein per lane. b Glucagon secretion from alphaTC1-9 cells treated with metformin. Cells pretreated with or without $500 \mu \mathrm{mol} / 1$ metformin in DMEM-based medium containing $17 \mathrm{mmol} / 1$ glucose for $16 \mathrm{~h}$ were preincubated in $\mathrm{KBH}$ solution containing $10 \mathrm{mmol} / 1$ glucose at $37^{\circ} \mathrm{C}$ with agitation $(120 \mathrm{rpm})$ for $30 \mathrm{~min}$ before incubation in $\mathrm{KBH}$ solution supplemented with 0 (white bars) or 17 (black bars) $\mathrm{mmol} / \mathrm{l}$ glucose with or without $500 \mu \mathrm{mol} / \mathrm{l}$ metformin for $30 \mathrm{~min}$ as indicated. c, d AlphaTC1-9 cells were incubated for 40 to $60 \mathrm{~min}$ in $\mathrm{KBH}$ containing the indicated glucose concentrations and $500 \mu \mathrm{mol} / 1 \mathrm{~A}-769662$, as shown, before cell lysis and immunoblotting using $50 \mu \mathrm{g}$ protein per lane (c) or glucagon assay as in $\mathbf{b}$ (white bars, $0.1 \mathrm{mmol} / \mathrm{l}$ glucose; black bars, $17 \mathrm{mmol} / \mathrm{l}$ glucose) (d). Western (immuno-) blot analysis (e) and glucagon secretion (f) in alphaTC1-9 cells treated with phenformin and/or compound C. AlphaTC1-9 cells were preincubated in $\mathrm{KBH}$ solution containing $10 \mathrm{mmol} / 1$ glucose at $37^{\circ} \mathrm{C}$ with agitation $(120 \mathrm{rpm})$ for $30 \mathrm{~min}$. KBH solution containing 0 (white bars) and 17 (black bars) $\mathrm{mmol} / 1$ glucose in addition to $1 \mathrm{mmol} / \mathrm{l}$ phenformin and $20 \mu \mathrm{mol} /$ 1 compound $\mathrm{C}$ were then added onto cells and cells were incubated at $37^{\circ} \mathrm{C}$ with agitation for $1 \mathrm{~h}$ before western (immuno-) blotting, using $80 \mu \mathrm{g}$ protein per lane (e) or glucagon secretion analysis (f). Shown are blots representative of at least three independent experiments. Data are means \pm SEM. ${ }^{*} p<0.05,{ }^{* *} p<0.01,{ }^{* * *} p<0.001$

\section{Discussion}

Several theories have been posited as to the nature of the signal transduction pathway(s) that mediate the direct inhibitory effects of high glucose on individual alpha cells. First, it has been suggested that a limited degree of $\mathrm{K}_{\mathrm{ATP}}$ channel closure occurs as the ATP/ADP ratio rises in response to glucose. This then leads to a limited depolarisation, and the inactivation of voltage-sensitive $\mathrm{Na}^{+}$and Ttype $\mathrm{Ca}^{2+}$ channels $[24,34]$, terminating action potential firing, $\mathrm{Ca}^{2+}$ oscillations and ultimately glucagon release. In a separate hypothesis, ATP-dependent stimulation of $\mathrm{Ca}^{2+}$

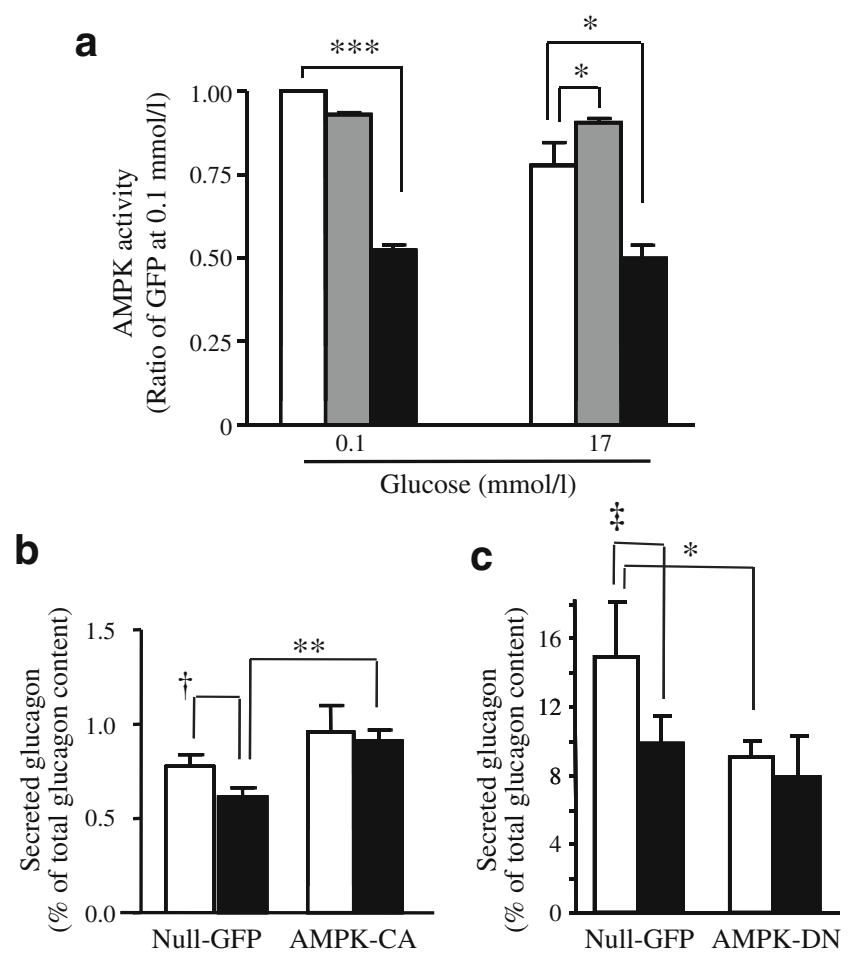

Fig. 3 Effects of molecular modulation of AMPK activity on glucagon secretion in alphaTC1-9 cells. a AMPK activity in alphaTC1-9 cells overexpressing AMPK-CA $\left(\alpha 1^{312}\right.$ T172D) and AMPK-DN ( $\alpha 1$ D157A). AlphaTC1-9 cells were infected with NullGFP (white bars), AMPK-CA (grey bars) or AMPK-DN (black bars) viruses at an MOI of 100 units/cell $48 \mathrm{~h}$ before glucose stimulation at 0.1 and $17 \mathrm{mmol} / \mathrm{l}$ for $2 \mathrm{~h}$ in Dulbecco's modified Eagle's medium. After being washed in PBS containing 0.1 and $17 \mathrm{mmol} / 1$ glucose three times, as indicated, cells were lysed and $20 \mu \mathrm{g}$ whole cell lysates were used for AMPK measurements, as described in Methods. Data are means \pm SEM of three separate experiments. ${ }^{*} p<0.05,{ }^{* * *} p<0.001$. b, c Glucagon secretion assay in alphaTC1-9 cells following adenoviral overexpression of AMPK-CA (b) and AMPK-DN (c). AlphaTC1-9 cells were cultured in 12-well plates and infected with null (expressing GFP only), AMPK-CA (b, white bars, $0.1 \mathrm{mmol} / 1$ glucose, black bars, $17 \mathrm{mmol} / 1$ glucose) or AMPK-DN (c, white bars, $0 \mathrm{mmol} /$ 1 glucose, black bars, $17 \mathrm{mmol} / 1$ glucose) adenoviruses at an MOI of 100 units/cell for $48 \mathrm{~h}$ before glucagon assays were performed at low or high glucose concentrations as described in Methods. Data are means \pm SEM of at least three separate experiments. ${ }^{*} p<0.05$, ${ }^{\dagger} p=0.063,{ }^{\ddagger} p=0.089$ 
a

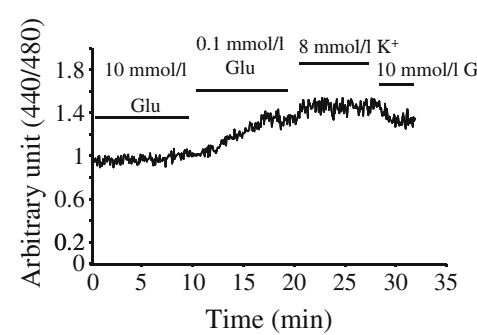

b

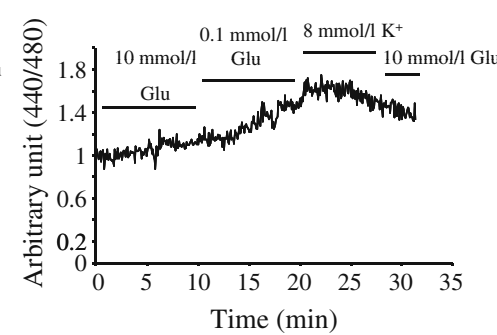

C

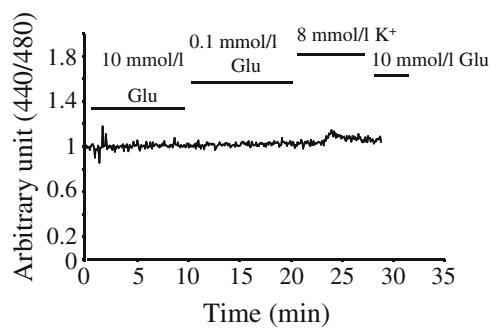

Fig. 4 Effects of forced changes in AMPK activity on cytosolic $\mathrm{Ca}^{2+}$ influx in $\alpha \mathrm{TC} 1-9$ cells. a-c $\left[\mathrm{Ca}_{\mathrm{cyt}}{ }^{2+}\right]$ measurement in alphaTC1-9 cells overexpressing AMPK-CA $\left(\alpha 1^{312}\right.$ T172D) and AMPK-DN $(\alpha 1$ D157A). AlphaTC1-9 cells were infected with null-GFP (a), AMPKCA (b) or AMPK-DN (c) viruses at an MOI of 100 units/cell $48 \mathrm{~h}$

uptake into the endoplasmic reticulum, and hence the decreased activity of a $\mathrm{Ca}^{2+}$-regulated plasma membrane current, has been proposed to lead to membrane hyperpolarisation, and so to decreased $\mathrm{Ca}^{2+}$ influx across the plasma membrane [35]. Measurements of alpha cell membrane potentials in the intact islet are challenging, although a study using rat, mouse and human islets suggested that elevated glucose concentrations do indeed cause alpha cell hyperpolarisation in all three species [36]. However, the latter study provided no further information on the mechanisms involved or the relative importance of paracrine (via changes in beta cell secretion) compared with direct effects of glucose on the alpha cell. Moreover, and in apparent contradiction to this finding, MacDonald et al. [37] have recently reported that the inhibitory effects of glucose on $\mathrm{Ca}^{2+}$ oscillations were partially reversed by low concentrations of diazoxide, presumably by re-opening $\mathrm{K}_{\mathrm{ATP}}$ channels and so repolarising the plasma membrane to a level at which $\mathrm{Na}^{+}$channels are inactive and action potential firing does not occur.

Indeed, there remain several key areas of uncertainty with regards to the mechanism of action of glucose. First, it before $\left[\mathrm{Ca}_{\mathrm{cyt}}{ }^{2+}\right]$ measurement with $200 \mathrm{nmol} / \mathrm{l}$ Fura-Red AM dissolved in $\mathrm{KBH}$ solution containing $10 \mathrm{mmol} / \mathrm{l}$ glucose was loaded onto cells $30 \mathrm{~min}$ before cells were perfused with $\mathrm{KBH}$ solution supplemented with glucose and $\mathrm{KCl}$ as indicated. These are representative traces of at least three separate experiments

has been unclear until recently whether free ATP concentrations (or ATP/ADP ratio) actually fluctuate in alpha cells in response to glucose. Hence, glucose-induced changes in total adenine nucleotide levels were difficult to demonstrate in FACS-purified rat alpha cells [38]. Our own recent studies [5], using a recombinant alpha cell targeted firefly luciferase and photon counting imaging, and those of others [39], demonstrated small ( $\sim 5 \%$ vs $15-20 \%$ in beta cells) $[26,40]$, but nonetheless clear, increases in free [ATP] in single alpha cells as glucose was raised over the range 1-20 mmol/1 [5].

In designing the present study we reasoned that a glucose-induced increase in ATP/ADP ratio, in addition to closing ATP-sensitive $\mathrm{K}^{+}$channels, would be likely to inhibit AMPK activity. Using a glucose-responsive alpha cell line, alphaTC1-9 cells, in which biochemical assays were feasible, we now provide direct support for this hypothesis. We demonstrate first that glucose strongly modulated both intracellular ATP levels (Fig. 1) and AMPK activity (Fig. 2) in these cells. While the observed changes largely occurred at relatively low glucose concentrations a

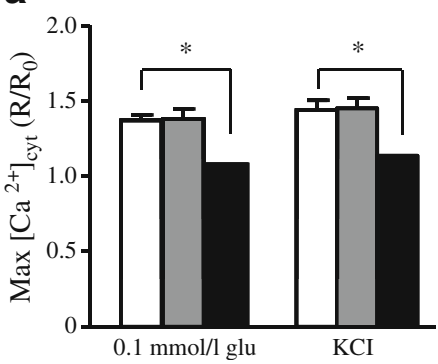

b

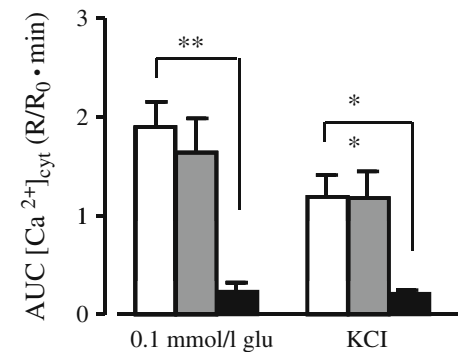

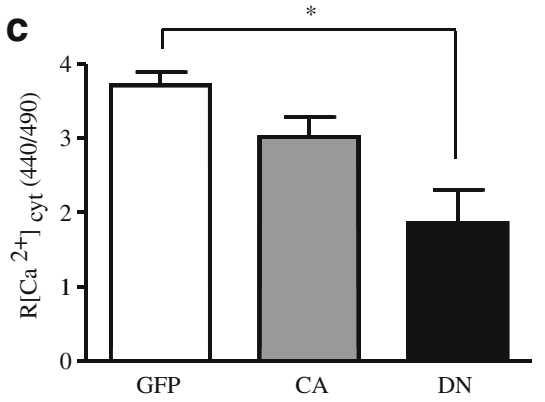

Fig. 5 Quantification of $\left[\mathrm{Ca}^{2+}\right]_{\mathrm{i}}$ measurement in alphaTC1-9 cells overexpressing AMPK-CA $\left(\alpha 1^{312}\right.$ T172D) and AMPK-DN $(\alpha 1$ D157A). Peak levels (a) and AUC (b) of cytosolic $\mathrm{Ca}^{2+}$ responses to $0.1 \mathrm{mmol} / 1$ glucose and $8 \mathrm{mmol} / \mathrm{K} \mathrm{KCl}$ in alphaTC1-9 cells overexpressing Null-GFP (white bars), AMPK-CA (grey bars) and AMPKDN (black bars) adenoviruses. Data were normalised to $\left[\mathrm{Ca}^{2+}\right]_{\mathrm{i}}(\mathrm{R} 0)$ levels at the beginning of perfusion of $10 \mathrm{mmol} / 1$ glucose. $\mathbf{c}$ Mean values of cytosolic $\mathrm{Ca}^{2+}\left(\mathrm{R}\left[\mathrm{Ca}^{2+}\right]_{\mathrm{i}}\right)$ levels in alphaTC1-9 cells overexpressing AMPK-CA (grey bars) and AMPK-DN (black bars) compared with cells overexpressing GFP (white bars) only as measured at $10 \mathrm{mmol} / \mathrm{l}$ glucose. Data are means \pm SEM of three separate experiments containing 19-23 cells per experiment for each virus. ${ }^{*} p<0.05,{ }^{*} p<0.01$ 
a

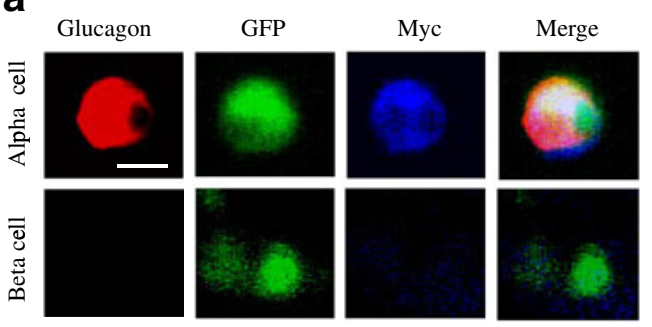

Fig. 6 Alpha cell-targeted expression of AMPK-CA stimulates glucagon secretion from mouse pancreatic islets. a Immunofluorescence staining of dissociated mouse pancreatic islets infected with PPG-AMPK-CA virus. Mouse pancreatic islets infected with PPGAMPK-CA virus, also expressing GFP under a distinct CMV promoter, for $48 \mathrm{~h}$ at an MOI of 100 units/cell, were dissociated into single cells and stained with rabbit anti-glucagon antibody $(1: 1,000)$ and mouse anti-myc antibody (1:100). Infected cells are shown in green (expressing GFP), glucagon-positive cells are shown in red and cells expressing myc-tagged AMPK-CA are shown in blue. Scale bar,

$(<1.0 \mathrm{mmol} / \mathrm{l})$ this result was expected in this cell line, in which the dose response to glucose of $\mathrm{Ca}^{2+}$ responses and glucagon release are also left-shifted with respect to primary alpha cells, most likely as a result of the modest overexpression of low $\mathrm{K}_{\mathrm{M}}$ hexokinases [5]. The lowglucose stimulated $\mathrm{Ca}^{2+}$ responses in this cell line reported in this study confirm our previous findings in isolated mouse pancreatic islets [5], although they contrast with the inhibitory effect of glucose on $\mathrm{Ca}^{2+}$ oscillation published by Olsen et al. [41]. We would note that the alpha cells used in the report by Olsen et al. [41] were purified by FACS, a procedure, which may conceivably have altered the electrophysiological and other properties of the cells. Unexpectedly, however, we did not observe any impact of AICAR on AMPK activity levels or T172 phosphorylation in alphaTC1-9 cells despite the robust glucose-dependent changes in the latter. As AMP/ATP-dependent changes in AMPK activity, generally believed to be mediated by liver kinase B1, were readily apparent in these cells, the latter finding might be explained by relatively poor rates of uptake or phosphorylation of AICAR by alpha cells. We would note, nonetheless, that increases in cytosolic $\mathrm{Ca}^{2+}$ following changes in influx across the plasma or endoplasmic reticulum membranes may also enhance AMPK at low glucose concentrations via the activation of calcium mitogen-activated protein kinase kinase $\beta$ [42-44]

Of particular significance we also show here that imposed increases in AMPK activity, achieved either through molecular genetic or pharmacological means and in either clonal alpha cells or primary islets, leads to an increase in glucagon secretion. By what molecular mechanisms might this occur? As intracellular free $\mathrm{Ca}^{2+}$ levels were not affected by AMPK activation at either low or high glucose (Fig. 4) it seems unlikely that this manoeuvre alone
C

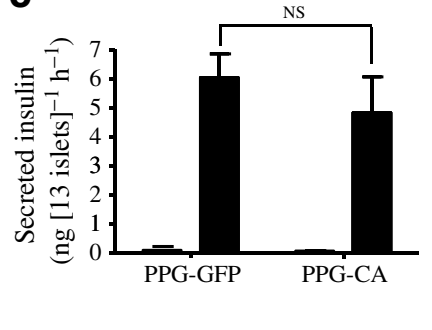

$5 \mu \mathrm{m}$. b Glucagon secretion of mouse pancreatic islets infected with PPG-AMPK-CA virus. Thirteen size-matched mouse pancreatic islets infected with Null-GFP (white bars) or PPG-AMPK-CA (grey bars) virus at an MOI of 100 units/cell for $48 \mathrm{~h}$ were preincubated in $\mathrm{KBH}$ solution containing $10 \mathrm{mmol} / 1$ glucose for $30 \mathrm{~min}$ then incubated in $\mathrm{KBH}$ supplemented with 0.1 or $17 \mathrm{mmol} / 1$ glucose for $1 \mathrm{~h}$ at $37^{\circ} \mathrm{C}$ with agitation $(120 \mathrm{rpm})$. Glucagon assay was performed as described in Methods. c Insulin assay performed on the islets described in $\mathbf{b}$. White bars, $0 \mathrm{mmol} / 1$ glucose, black bars, $17 \mathrm{mmol} / 1$ glucose. Data are means \pm SEM of three separate experiments. ${ }^{*} p<0.05$

is sufficient to depolarise the plasma membrane and elicit glucagon secretion during glucose deprivation. On the other hand, as inhibition of AMPK activity suppressed $\mathrm{Ca}^{2+}$ increases at low glucose, it would appear that increases in AMPK activity are required for enhanced electrical activity. One possible mediator of the latter effect is the activation of $\mathrm{K}_{\text {ATP }}$ channels, whose trafficking to the cell surface was recently shown to be enhanced by AMPK in pancreatic islet beta cells [45], an event which, in the alpha cell, would be expected to lead to membrane hyperpolarisation to a level permissive for action potential firing [34]. An apparently paradoxical observation of the present studies is that, in contrast to pancreatic beta cells, in which AMPK activation suppresses insulin vesicle trafficking and decreases insulin secretion [19], in alpha cells AMPK enhanced hormone release, at least in part, independently of $\left[\mathrm{Ca}^{2+}\right]_{i}$. We have suggested that the inhibitory effect of AMPK on insulin secretion may be the result of phosphorylation by AMPK of kinesin light chain kinesin-1 (KLC-1), which occurs vigorously in vitro but the impact of which on KLC-1 activity and vesicle mobility remains unproven [46]. Importantly, AMPK activation exerted no effect on the kinetics of exocytosis by pre-docked granules in beta cells [19]. Although the relative importance of vesicle recruitment (i.e. subcellular translocation to sites of exocytosis) and the stimulated exocytosis of predocked glucagon granules in the response of alpha cells to glucose deprivation is undefined, our data strongly indicate that AMPK activates glucagon secretion downstream of $\mathrm{Ca}^{2+}$ increases, either by increasing the number of docked granules or their competence for fusion. Further studies will be necessary to address these complex mechanistic questions.

In conclusion we demonstrate here that changes in AMPK activity provide a further means through which 
alpha cells translate a change in extracellular glucose concentrations into a secretory response. Given the ability of several glucose-lowering agents, including the biguanide metformin as well as the thiazolidinediones, to activate AMPK at least in some tissues [3] the impact of these agents on glucagon release may deserve closer scrutiny. Importantly, agents that may inhibit islet AMPK activity may perform a dual role to stimulate insulin secretion and inhibit glucagon release, both endpoints likely to be of benefit in the treatment of all forms of diabetes mellitus.

Acknowledgements This work was supported by grants to G.A. Rutter from the Wellcome Trust (Programme Grant 081958/2/07/Z), The European Union (FP6 'Save Beta'), the Medical Research Council (G0401641) and National Institutes of Health (RO1 DK071962-01), and to I. Leclerc from the Wellcome Trust (Project grant WT082366MA). We thank J. Philippe (University of Geneva) for the kind provision of the PPG promoter and G. Hardie (University of Dundee) for the kind gift of A-769962.

Duality of interest The authors declare that there is no duality of interest associated with this manuscript.

\section{References}

1. Gelling RW, Du XQ, Dichmann DS et al (2003) Lower blood glucose, hyperglucagonemia, and pancreatic alpha cell hyperplasia in glucagon receptor knockout mice. Proc Natl Acad Sci USA 100:1438-1443

2. Gromada J, Franklin I, Wollheim CB (2007) Alpha-cells of the endocrine pancreas: 35 years of research but the enigma remains. Endocr Rev 28:84-116

3. Rutter GA (2009) Regulating glucagon secretion: somatostatin in the spotlight. Diabetes 58:299-301

4. Bailey SJ, Ravier MA, Rutter GA (2007) Glucose-dependent regulation of gamma-aminobutyric acid (GABA A) receptor expression in mouse pancreatic islet alpha-cells. Diabetes 56:320-327

5. Ravier MA, Rutter GA (2005) Glucose or insulin, but not zinc ions, inhibit glucagon secretion from mouse pancreatic alphacells. Diabetes 54:1789-1797

6. Kahn BB, Alquier T, Carling D, Hardie DG (2005) AMPactivated protein kinase: ancient energy gauge provides clues to modern understanding of metabolism. Cell Metab 1:15-25

7. Towler MC, Hardie DG (2007) AMP-activated protein kinase in metabolic control and insulin signaling. Circ Res 100:328-341

8. Hawley SA, Boudeau J, Reid JL et al (2003) Complexes between the LKB1 tumor suppressor, STRADalpha/beta and MO25alpha/ beta are upstream kinases in the AMP-activated protein kinase cascade. J Biol 2:28

9. Woods A, Johnstone SR, Dickerson K et al (2003) LKB1 is the upstream kinase in the AMP-activated protein kinase cascade. Curr Biol 13:2004-2008

10. Stahmann N, Woods A, Carling D, Heller R (2006) Thrombin activates AMP-activated protein kinase in endothelial cells via a pathway involving $\mathrm{Ca}^{2+} /$ calmodulin-dependent protein kinase kinase beta. Mol Cell Biol 26:5933-5945

11. Hardie DG, Carling D, Carlson M (1998) The AMP-activated/ SNF1 protein kinase subfamily: metabolic sensors of the eukaryotic cell? Annu Rev Biochem 67:821-855
12. Thelander M, Olsson T, Ronne H (2004) Snfl-related protein kinase 1 is needed for growth in a normal day-night light cycle. EMBO J 23:1900-1910

13. Narbonne P, Roy R (2009) Caenorhabditis elegans Dauers need LKB1/AMPK to ration lipid reserves and ensure long-term survival. Nature 457:210-214

14. Zhou G, Myers R, Li Y et al (2001) Role of AMP-activated protein kinase in mechanism of metformin action. J Clin Invest 108:1167-1174

15. Han SM, Namkoong C, Jang PG et al (2005) Hypothalamic AMPactivated protein kinase mediates counter-regulatory responses to hypoglycaemia in rats. Diabetologia 48:2170-2178

16. Leclerc I, Kahn A, Doiron B (1998) The 5'AMP-activated protein kinase inhibits the transcriptional stimulation by glucose in liver cells, acting through the glucose response complex. FEBS Lett 431:180-184

17. Alquier T, Kawashima J, Tsuji Y, Kahn BB (2007) Role of hypothalamic adenosine $5^{\prime}$-monophosphate-activated protein kinase in the impaired counterregulatory response induced by repetitive neuroglucopenia. Endocrinology 148:1367-1375

18. McCrimmon RJ, Fan X, Cheng $\mathrm{H}$ et al (2006) Activation of AMP-activated protein kinase within the ventromedial hypothalamus amplifies counterregulatory hormone responses in rats with defective counterregulation. Diabetes 55:1755-1760

19. Tsuboi T, da Silva XG, Leclerc I, Rutter GA (2003) 5'-AMPactivated protein kinase controls insulin-containing secretory vesicle dynamics. J Biol Chem 278:52042-52051

20. da Silva XG, Leclerc I, Varadi A, Tsuboi T, Moule SK, Rutter GA (2003) Role for AMP-activated protein kinase in glucosestimulated insulin secretion and preproinsulin gene expression. Biochem J 371:761-774

21. Leclerc I, Woltersdorf WW, da Silva XG et al (2004) Metformin, but not leptin, regulates AMP-activated protein kinase in pancreatic islets: impact on glucose-stimulated insulin secretion. Am J Physiol Endocrinol Metab 286:E1023-E1031

22. Targonsky ED, Dai F, Koshkin V et al (2006) Alpha-lipoic acid regulates AMP-activated protein kinase and inhibits insulin secretion from beta cells. Diabetologia 49:1587-1598

23. Richards SK, Parton LE, Leclerc I, Rutter GA, Smith RM (2005) Over-expression of AMP-activated protein kinase impairs pancreatic beta-cell function in vivo. J Endocrinol 187:225-235

24. Sun G, Tarasov AI, McGinty J et al (2010) Ablation of AMPactivated protein kinase alpha1 and alpha2 from mouse pancreatic beta cells and RIP2.Cre neurons suppresses insulin release in vivo. Diabetologia 53:924-936

25. He TC, Zhou S, da Costa LT, Yu J, Kinzler KW, Vogelstein B (1998) A simplified system for generating recombinant adenoviruses. Proc Natl Acad Sci USA 95:2509-2514

26. Ainscow EK, Rutter GA (2001) Mitochondrial priming modifies $\mathrm{Ca}^{2+}$ oscillations and insulin secretion in pancreatic islets. Biochem J 353:175-180

27. Woods A, Azzout-Marniche D, Foretz M et al (2000) Characterization of the role of AMP-activated protein kinase in the regulation of glucose-activated gene expression using constitutively active and dominant negative forms of the kinase. Mol Cell Biol 20:6704-6711

28. Noordeen NA, Khera TK, Sun G et al (2009) Carbohydrateresponsive element-binding protein (ChREBP) is a negative regulator of ARNT/HIF-1beta gene expression in pancreatic islet beta-cells. Diabetes 59:153-160

29. Tarasov AI, Nicolson TJ, Riveline JP et al (2008) A rare mutation in ABCC8/SUR1 leading to altered ATP-sensitive $\mathrm{K}^{+}$channel activity and beta-cell glucose sensing is associated with type 2 diabetes in adults. Diabetes 57:1595-1604

30. Hardie DG (2006) Neither LKB1 nor AMPK are the direct targets of metformin. Gastroenterology 131:973, author reply 974-975 
31. Scott JW, van Denderen BJ, Jorgensen SB et al (2008) Thienopyridone drugs are selective activators of AMP-activated protein kinase beta1-containing complexes. Chem Biol 15:1220 1230

32. Cool B, Zinker B, Chiou W et al (2006) Identification and characterization of a small molecule AMPK activator that treats key components of type 2 diabetes and the metabolic syndrome. Cell Metab 3:403-416

33. Owen MR, Doran E, Halestrap AP (2000) Evidence that metformin exerts its anti-diabetic effects through inhibition of complex 1 of the mitochondrial respiratory chain. Biochem J 348 (Pt 3):607-614

34. Gopel SO, Kanno T, Barg S, Weng XG, Gromada J, Rorsman P (2000) Regulation of glucagon release in mouse-cells by KATP channels and inactivation of TTX-sensitive $\mathrm{Na}^{+}$channels. J Physiol 528:509-520

35. Liu YJ, Vieira E, Gylfe E (2004) A store-operated mechanism determines the activity of the electrically excitable glucagonsecreting pancreatic alpha-cell. Cell Calcium 35:357-365

36. Manning Fox JE, Gyulkhandanyan AV, Satin LS, Wheeler MB (2006) Oscillatory membrane potential response to glucose in islet beta-cells: a comparison of islet-cell electrical activity in mouse and rat. Endocrinology 147:4655-4663

37. MacDonald PE, De Marinis YZ, Ramracheya R et al (2007) A K ATP channel-dependent pathway within alpha cells regulates glucagon release from both rodent and human islets of Langerhans. PLoS Biol 5:e143

38. Detimary P, Dejonghe S, Ling Z, Pipeleers D, Schuit F, Henquin JC (1998) The changes in adenine nucleotides measured in glucose-stimulated rodent islets occur in beta cells but not in alpha cells and are also observed in human islets. J Biol Chem 273:33905-33908
39. Ishihara H, Maechler P, Gjinovci A, Herrera PL, Wollheim CB (2003) Islet beta-cell secretion determines glucagon release from neighbouring alpha-cells. Nat Cell Biol 5:330-335

40. Kennedy HJ, Pouli AE, Ainscow EK, Jouaville LS, Rizzuto R, Rutter GA (1999) Glucose generates sub-plasma membrane ATP microdomains in single islet beta-cells. Potential role for strategically located mitochondria. J Biol Chem 274:1328113291

41. Olsen HL, Theander S, Bokvist K, Buschard K, Wollheim CB, Gromada J (2005) Glucose stimulates glucagon release in single rat alpha-cells by mechanisms that mirror the stimulus-secretion coupling in beta-cells. Endocrinology 146:4861-4870

42. Hurley RL, Anderson KA, Franzone JM, Kemp BE, Means AR, Witters LA (2005) The $\mathrm{Ca}^{2+} /$ calmodulin-dependent protein kinase kinases are AMP-activated protein kinase kinases. J Biol Chem 280:29060-29066

43. Hawley SA, Pan DA, Mustard KJ et al (2005) Calmodulindependent protein kinase kinase-beta is an alternative upstream kinase for AMP-activated protein kinase. Cell Metab 2:9-19

44. Woods A, Dickerson K, Heath $\mathrm{R}$ et al (2005) $\mathrm{Ca}^{2+}$ calmodulin-dependent protein kinase kinase-beta acts upstream of AMP-activated protein kinase in mammalian cells. Cell Metab 2:21-33

45. Lim A, Park SH, Sohn JW et al (2009) Glucose deprivation regulates KATP channel trafficking via AMP-activated protein kinase in pancreatic beta-cells. Diabetes 58:2813-2819

46. McDonald A, Fogarty S, Leclerc I, Hill EV, Hardie DG, Rutter GA (2010) Cell-wide analysis of secretory granule dynamics in three dimensions in living pancreatic beta-cells: evidence against a role for AMPK-dependent phosphorylation of KLC1 at Ser517/ Ser520 in glucose-stimulated insulin granule movement. Biochem Soc Trans 38:205-208 